\title{
Industry-Finance Integration and Corporate Innovation
}

\author{
Yu Meng \\ Jinan University, Guangzhou, China \\ Email: cynthia2287458@163.com
}

How to cite this paper: Meng, Y. (2020). Industry-Finance Integration and Corporate Innovation. Modern Economy, 11, 292-321.

https://doi.org/10.4236/me.2020.112025

Received: December 19, 2019

Accepted: February 7, 2020

Published: February 10, 2020

Copyright $\odot 2020$ by author(s) and Scientific Research Publishing Inc. This work is licensed under the Creative Commons Attribution International License (CC BY 4.0).

http://creativecommons.org/licenses/by/4.0/ (c) (i) Open Access

\begin{abstract}
This article takes China's A-share listed companies from 2008 to 2017 as a sample to study the relationship between industry-finance integration and corporate innovation, and discusses the differential impact of industry-finance integration on corporate innovation under different agency costs and financing constraints. In addition, in order to clarify the path that the combination of industry and finance affects corporate innovation, this article further explores the mechanism of the combination of industry and finance on corporate innovation. The study found that at this stage, the integration of domestic and domestic financing has a significant "crowding out" effect on corporate innovation, and this "crowding out" effect is even more pronounced in companies with higher agency costs and greater financing constraints. After controlling for endogeneity and performing a robustness test, the conclusion still holds. Further mechanism inspections have shown that the combination of production and finance increases the business risk of the enterprise, which in turn crowds out innovation. The above research conclusions show that at the current stage, the combination of industry and finance of listed companies in China has not effectively achieved the long-term strategic goals of the enterprise, but has increased the business risk of the enterprise, inhibited the innovation investment of the enterprise, and caused the real economy to face a situation of "depreciation to reality" threat. This article provides micro-level evidence for China's domestic financial integration practice, and has certain reference significance for how regulatory authorities can guide the integration of industry and financial integration and how Chinese enterprises can prevent and control financial risks. The main contribution of this article is to combine the institutional background of China's economic transformation and consider the differences between the internal and external environments facing different companies. The empirical analysis tests the relationship between the combination of industry and finance and corporate innovation. In addition, the role of this relationship is further stu-
\end{abstract}


died from the perspective of operational risk, which provides a certain decision-making reference for Chinese enterprises on how to improve the effectiveness of the combination of industry and finance.

\section{Keywords}

Industry-Finance Integration, Corporate Innovation, Agency Costs, Financing Constraints, Operating Risk

\section{Introduction}

As China's economic development enters a critical transition period, how to promote industrial transformation and upgrading and promote economic development has become the key. In an environment of increasingly fierce global competition, innovation is an important way to improve the core competitiveness of enterprises and an important driving force for the high-quality development of a country's economy (Solow, 1957; Porter, 1992). In recent years, with the advancement of China's innovation-driven strategy, corporate innovation capabilities have improved, and R \& D investment has continued to increase, but there is still a large gap compared with developed countries. Innovation activities require a large amount of capital investment. The internal funds of enterprises are often difficult to meet, especially in recent years, due to the impact of internal and external environments, the profit rate of physical enterprises has continued to decline, resulting in continuous decline in internal capital support for corporate $\mathrm{R} \& \mathrm{D}$ and innovation. The high risks, high adjustment costs, and uncertainty of innovation activities have exacerbated external financing constraints (Paul, 1990; Hall \& Lerner, 2010). In this case, how to find stable financial support for innovation activities has become the key to improving the innovation capacity of enterprises.

Industrial-financial integration is a new organizational model. By organically combining industrial capital and financial capital, the two capitals can be interconnected and become a new path for enterprises to seek their own development in the new situation. Especially in the context of the declining profits of China's real enterprises and the high profits of the financial industry, more and more real companies have begun to lay out the financial sector in an attempt to share the excess profits of the financial industry. Integration has aroused social concern. In the short term, companies entering the financial sector can share the high profits of the financial industry and promote income growth, but this short-term prosperity comes at the expense of long-term growth. The practice of the combination of industry and finance in China shows that more and more companies are starting to deviate from their original intentions and driven by financial speculation, and are keen on financial speculation, which eventually leads to industrial investment being squeezed out and the economy is moving towards "destabilization" (Du et al., 2019). The report of the 19th National Con- 
gress of the Communist Party of China stated that "the focus must be on the real economy" and "deepening the reform of the financial system and improving the ability of financial services to the real economy". The government work report also emphasized that "we must do a good job of reforming the financial system to prevent the economy from becoming destabilized". Therefore, in the critical transition period of China's economic development, how to grasp the balance between the real economy and financial development, improve the effectiveness of the combination of industry and finance, and provide the impetus for the strategic transformation and innovation and upgrading of real enterprises is a question worthy of attention. Based on the above background, this article focuses on the relationship between China's domestic integration and corporate innovation during the economic transformation process, attempts to deeply explore the impact of industry-finance integration on corporate innovation, and clarifies its micro-mechanism in order to provide empirical evidence for China 's domestic integration.

This article takes the phenomenon of industrial capital distribution in the financial field as a starting point, and studies the impact of industrial-financial integration on corporate innovation. The possible innovations here are as follows:

Based on the institutional background of China's economic transformation, this paper tests the impact of industry-finance integration on corporate innovation through empirical analysis, provides empirical evidence for a deeper understanding of the microeconomic expectations of industry-finance integration, and enriches the research perspective of existing literature.

Second, the heterogeneity of internal and external factors in different companies is considered here. The internal and external environment facing different companies may be different, and the impact of industrial-financial integration on corporate innovation may be different. Therefore, here we distinguish the difference between internal agency costs and external financing constraints, and further study the differential impact of the combination of industry and finance on corporate innovation under different agency costs and different financing constraints.

In order to clarify the mechanism of industry-finance integration on enterprise innovation, this article further studies the role of industry-finance integration in corporate innovation, and provides a certain decision-making reference for how Chinese enterprises can improve the effectiveness of industry-finance integration.

\section{Literature Review}

\subsection{Literature Review of Integration of Industry and Finance}

\subsubsection{Economic Drivers of Industry-Finance Integration}

1) Build a financing platform and seek funding support

Resource-based theory believes that resources between enterprises are heterogeneous. The scarcity and liquidity of resources determine that enterprises must 
expand into different markets to gain competitive advantage. Enterprises entering the financial field through the integration of industry and finance will help build a financing platform, broaden financing channels, and realize capital expansion. Alexander (1962) studied the industrial-financial integration behavior of modern enterprises, and found that in order to obtain an effective supply of capital to promote the integration of industrial capital and financial capital, the industrial-financial integration model can help enterprises to accumulate and circulate capital, thereby helping domestic industrialization development of. Xinchun Li (2011) used a questionnaire to study the relationship between the capital market and the growth of entrepreneurs. The survey results on the integration of industry and finance showed that the main motivation of entrepreneurs to integrate industry and finance was mostly to obtain more credit support and enhance financial flexibility. Chuanzhong Du, Fei Wang, and Yifei Jiang (2014) used the sequential DEA method to study the basic drivers of industrial-financial integration of industrial listed companies. The study found that financing needs, asset preservation, and development transformation were the main drivers of Chinese industrial enterprises' participation in financial institutions.

2) Towards diversified operations and gain synergy between industry and finance

In any business environment, no company can consider itself to be immune to outdated products and depleted demand. Therefore, when continuous operation in existing products or markets fails to meet its goals, companies must seek diversification opportunities. Diversification can achieve complementary advantages and maintain competitive advantages through financial coordination and production coordination. The combination of industry and finance combines the capital of two different industries, industrial capital and financial capital, to become a way for enterprises to achieve diversification and seek synergies. Li and Greenwood (2004) took companies entering the insurance industry as research objects, and found that industrial companies mainly adopted diversified strategies to enter the financial industry in order to obtain synergy effects. Yan Zhi, Hebei Wu (2011) explored the inherent logic of the combination of industry and finance from the perspective of endogenous competitive advantage and the internal motivation of the combination of industry and finance. The research found that the main driver of the integration of industry and finance is the use of dynamic capabilities to establish, integrate and reconfigure the internal External resources, knowledge, and capabilities to maintain the competitive advantage of the business.

3) Find profit growth points and share excess profits

According to the principle of average profit formation, in the case of uneven profit margins between industries, capital from low-margin industries must be transferred to high-margin industries, and the average social profit rate will eventually be realized. Due to the long-term relative monopoly of China's financial industry, the profit margin of the financial industry is higher than that of 
other industries. Listed companies have invested in financial institutions in order to obtain excess investment returns. Yuan Lin (2010) researched the effect of the integration of industry and finance in China's listed companies, and found that the integration of industry and finance in Chinese enterprises is mainly for industrial expansion and sharing of excess profits in the financial industry. Muxuan Guo and Hui Liao (2013) studied the motivation of the combination of industry and finance with the data of private equity banks in China. The research found that the motivation of private equity participation in banks is not from the pressure of financing constraints, but from the diversified operation and sharing of banking monopoly Profit considerations. Hongjian Wang, Yuqiang Cao (2017) and others when studying the phenomenon of listed companies in the manufacturing industry entering the financial industry in China, found that due to the fact that China's financial capital has exceeded the profit margin in the past, physical enterprises have invested in the financial industry to share the high profits of the financial industry. It appears as a market arbitrage behavior (Orhangazi, 2008).

\subsubsection{Economic Consequences of Industry-Finance Integration}

1) Positive effect of industry-finance integration

After the combination of industrial capital and financial capital, due to the existence of information effects and decision-making effects, the combination of industry and finance can effectively save the company's transaction costs, ease the financing constraints of the company, and achieve a positive impact on the development of the company. Laeven (2003) used Russian data for research and found that the mode of industry-finance integration can effectively reduce the information asymmetry between banks and enterprises, and banks are more inclined to lend to companies that hold a large amount of equity in banks. Liangyong Wan et al. (2015) studied the impact of the industrial-financial integration model of Chinese commercial banks on the financing constraints of enterprises, and found that the information and decision-making effects brought by the industrial-financial integration can help companies deepen the relationship between banks and enterprises and obtain financing convenience to ease financing constraints. Hui Zhou and Yue Tan (2018) explored the impact of industrial-financial integration strategies on corporate financing constraints in the context of industrial policies. The study found that industrial-financial integration eased financing constraints through information and related effects, and this effect is more significant in samples that are not supported by industrial policy. In addition, some studies have pointed out that the effectiveness of industrial-financial integration is related to the country's capital market, legal system, and government. The positive effects will be strengthened. Moreover, with the increase of the proportion of enterprises holding financial institutions, the combination of production and finance can effectively improve their operating performance, the total factor productivity of physical enterprises will also be significantly improved, and the main business income will also increase significantly. 
2) Negative effects of industry-finance integration

Although the phenomenon of industry-financial integration has been universal in China, most of the listed companies currently have a low degree of industry-financial integration and the level of industry-financial integration is not deep. To achieve the deep interaction between financial capital and the industrial chain, there is still a long way to go to achieve synergy between businesses. Therefore, in practice, the problems of negative effects and ineffectiveness of the combination of industry and finance also emerge endlessly. Qingliang Zhang and Jingtong Sun (2007) studied the impact of industry-finance integration on corporate performance by constructing a cost-benefit model of industry-finance integration. The study found that China's domestic-industry integration was still at an elementary level, and there were a large number of ineffective and negative effects in practice. Yuan Lin (2010) research found that after the listed company's participation in financial institutions, the operating performance indicators have declined significantly, and management coordination and financial coordination have not been achieved. The positive effect brought by the combination of industry and finance in listed companies in China on operating performance is not obvious. Some literatures found that the combination of industry and finance will also bring about rent-seeking problems for managers. The rent-seeking behavior of managers will distort the internal resource allocation of industry-finance integration and cause low investment efficiency. La Porta et al. (2003) studied the issue of internally-linked loans in enterprises. The study found that enterprises involved in banking are more likely to have connected loans, distorting resource allocation, and bringing negative impacts to enterprises. Wei'an Li and Chao Ma (2014) research found that the combination of industry and finance can provide financing convenience and alleviate insufficient investment, but this connection also exacerbates overinvestment. In addition, the high risk and high contagion of financial capital also exacerbated the risks of enterprises and adversely affected their operations. Yanling Chen (2006) believes that the combination of industry and finance can easily lead to portfolio risk, internal transaction risk, financial leverage risk, conflict of interest risk and moral risk. Hua Chen Wang (2004) pointed out that the combination of industry and finance complicates the ownership structure and exacerbates the transmission effect of financial risks. Dequan Yao, Shuai Wang et al. (2011) used the stochastic frontier method to introduce risk factors to evaluate the operating efficiency of a new listed company that combines industry and finance. The study also found that the operating efficiency of a listed company that combines industry and finance is low, and risk factors reduce the company's operation efficiency. Longtian Zhang (2017) found that there is a huge risk of large-scale state-owned enterprises' integration of industry and finance, which exacerbates information asymmetry, magnifies financial risks and spillover effects, while excessive spillovers will cause the virtual economy to bubble and adversely affect the national economy. 


\subsection{Literature Review of Enterprise Innovation}

\subsubsection{Macro Environment and Corporate Innovation}

The current research on the impact of macro environment on corporate innovation is mainly focused on financial development, market competition, and institutional environment. From the perspective of financial development, Teng Zhong and Changyun Wang (2017) measured financial development from three dimensions: the size of the stock market, the size of the banking industry, and the marketization of the banking industry. They found that the stock market is more conducive to promoting corporate patent innovation than the banking industry. In particular, it has a more significant impact on invention patents. Weimin Xie and Hongxing Fang (2011) examined the impact of regional financial development on corporate $\mathrm{R} \& \mathrm{D}$ investment. The study found that the advancement of market-oriented reforms in the banking industry and regional financial development have actively promoted the R \& D investment of listed companies in China. Lan Qi and Yebin Wang (2013) research found that the monopoly status of China's state-owned banks led to the concentrated flow of credit funds to state-owned enterprises, which caused non-state-owned enterprises to face severe financing constraints, which was not conducive to the improvement of technological innovation efficiency of enterprises. Min Pan and Gezhen Yuan (2019) found that financial intermediary innovation has an inverted U-shaped effect on the overall technological innovation of enterprises.

From the perspective of market competition, it mainly focuses on the test of Schumpeter's hypothesis. Schumpeter (1942) research found that companies with a monopoly position can provide continuous profit support for innovation activities, thereby enhancing their innovation capabilities. Changa and Wub (2006) also found that a long-term monopoly position can help companies to accumulate production experience, which in turn stimulates R \& D and innovation. However, there are also studies that believe that market competition is more motivating. Arrow (1962) research finds that with the increasing competition in the industry, the threats of bankruptcy and low profits faced by enterprises have also intensified, which will inevitably encourage enterprises to reduce innovation through innovation risk. Other studies suggest that there is a non-linear relationship between market competition and corporate innovation. From the perspective of the institutional environment, Yongjin Wang and Xiao Feng (2018) studied the impact of the reform of the administrative approval system on corporate innovation, and found that the establishment of the administrative approval center significantly improved the level of corporate innovation. Jiang, Wang, \& Bai (2013) analyzed the effect of environmental regulation on technological innovation, and the results showed that there is an inverted U-shaped characteristic between environmental regulation and technological innovation of enterprises. Lin, Lin, \& Deng (2013) examined the impact of the income tax reform on technological innovation, and found that the reduction of tax rates and the deduction of R \& D expenses jointly promote technological innovation in enterprises. 


\subsubsection{Internal Characteristics and Enterprise Innovation}

At the micro level, existing research focuses on the impact of property rights, corporate size, corporate governance, and executive characteristics on corporate innovation. From the perspective of property rights, Yanbing Wu (2012) research found that private enterprises are in a leading position in innovation input and patent innovation efficiency, foreign-owned enterprises have significant advantages in new product innovation efficiency and production efficiency, and state-owned enterprises lack competitiveness in innovation input, innovation efficiency and production efficiency. Yuejun Tang and Jingjing Zuo (2014) also found that private enterprises have higher levels of innovation and state-owned enterprises have lower innovation efficiency. From the perspective of enterprise scale, enterprises can generate economies of scale through expansion and merger and other expansion activities, which is conducive to the improvement of industrial technology. others reached the opposite conclusion, that the expansion of the company's scale makes the company's innovation incentives, decision-making and management slow and rigid, and cannot make appropriate judgments when facing crisis and opportunities. From the perspective of corporate governance, Tong Lu and Yin Dang (2014) research found that the second to tenth largest shareholders' shareholding ratios, fund shareholding ratios, and director-supervisor high shareholding ratios in the three industries have positive influences on R\&D investment. Rui Lu (2014) research found that ex-ante high-level compensation can promote company executives to engage in innovation investment, and the sensitivity of executive pay performance can restrict executives' opportunistic behavior after innovation investment. Desheng Zhu and Xiaopei Zhou (2016) research found that equity balance has a significant impact on the efficiency of corporate innovation, and enterprises with high equity balance have higher innovation efficiency. From the perspective of executive characteristics, Yihua Yu et al. (2018) found that inventor executives have a significant positive role in promoting $\mathrm{R} \& \mathrm{D}$ investment, innovation output, and innovation efficiency. Jianzhong Wang (2018) research found that there is an intergenerational age gap between the chairman and the CEO, which can promote corporate R \& D investment.

\subsection{Literature Review on the Relationship between Industry and Finance Integration and Corporate Innovation}

In recent years, with the promotion of innovation-driven strategies, the innovation behavior of enterprises has received a lot of attention in the theoretical world, and the relationship between the combination of industry and finance and enterprise innovation has also started to receive considerable attention.

Tadesse (2002) research finds that companies can help companies raise funds for innovative activities in the financial market by participating in financial institutions, and promote investment in research and development. Yang, Li, \& Liu (2019) pointed out that innovative activities require a large amount of financial support. Enterprises entering the financial field can share the high profits of 
the financial industry and provide a continuous source of funds for corporate $\mathrm{R}$ \& D activities. Li \& Cai (2019) studied the relationship between financial development and technological innovation. The research considered that capital is an endogenous variable of technological innovation, and the improvement of financial development has promoted technological innovation. Although equity-holding financial institutions can alleviate the external financing constraints of innovative activities to a certain extent, China's incomplete financial capital price formation mechanism has brought high profit returns to the financial industry. In the field, the phenomenon of "crowding out" of industrial investment and innovation is also getting worse. Xie, Wang, \& Jiang (2014) examined the impact of manufacturing financialization on technological innovation based on Euler's equation and systematic GMM method. The research found that excessive financialization of manufacturing industry squeezed out R \& D investment and suppressed technological innovation. Wang, Zhang, \& Xie (2016) distinguished between listed financial institutions and non-listed financial institutions, and found that non-listed financial institutions can ease financing constraints and promote R \& D output, but this effect is not significant in listed financial institutions. Xie \& Fang (2011) further explored the impact of non-financial companies' equity participation in the financial industry on corporate innovation. The study found that participating financial institutions inhibited corporate innovation, and that the inhibitory effect was more pronounced in companies facing financing constraints and pressure on management performance. Wang, Li, \& Tang (2016) analyzed the impact of physical financialization on technological innovation based on market arbitrage theory. The study found that there is an excess rate of return in China's financial industry.

Through the review of the above documents, it can be found that the existing literature focuses on the phenomenon of the combination of industry and finance mainly focused on its economic drivers and economic consequences, and has not yet reached a consensus conclusion. The research on corporate innovation focuses more on the perspectives of macro factors such as financial development and micro-factors such as internal characteristics of the company. Only part of the literature focuses on the impact of the combination of industry and finance on corporate innovation behavior, and the conclusions also differ greatly. With the rapid development of China's domestic integration, corporate activities, especially corporate innovation activities, will inevitably be affected. In addition, given that companies may enter the financial sector for different motivations, the resulting economic effects may also vary widely. Looking at existing research, in addition to reducing transaction costs and alleviating information asymmetry, companies entering the financial field are more in order to share the high profits of the financial industry, especially in recent years. The real economy's profits have narrowed, and the ultra-high return on capital in the financial industry has induced more and more real companies to enter the financial sector for capital arbitrage. At this stage, this "impure motive" combination of industry and finance will affect companies. The impact of innovation has received much 
attention. Based on this, this article takes the industry-financial integration behavior as the starting point to test the relationship between industry-finance integration and enterprise innovation, hoping to provide empirical evidence for a deeper understanding of the role of industry-finance integration in micro-enterprises' innovation behavior.

\section{Theoretical Analysis and Research Hypothesis}

\subsection{Impact of Industry-Finance Integration on Enterprise Innovation}

The average profit theory believes that capital is profit-by-profit. When there are differences in profitability between industries, it will inevitably attract capital from a low-margin industry to a high-margin industry. At this stage, China's economy is in a period of transformation and upgrading. With the changes in the domestic and foreign economic situations, the main economy's main profit rate has continued to slump, and the financial industry enjoys excess profits due to its long-term relative monopoly position. Driven by the profitability of capital, real enterprises can quickly enter the financial industry through the combination of industry and finance to share excess returns, and this "impure motivation" industry and finance combination is more manifested as a market arbitrage behavior and inhibits the company's innovation investment. On the other hand, the scarcity of resources and liquidity determine that companies must enter different markets to gain a competitive advantage, and thus embark on the road of capital expansion. In the process of corporate capital expansion, companies have gradually evolved from value creators to value appraisers, and financial investment has become an inevitable choice. And when the company's freely controlled resources are limited, the company will give priority to the financial supply of financial investments that can obtain high profits rather than high-risk research and development investments, which will inevitably lead to a reduction in the funds available for research and development investments. Existing research also proves this conclusion. They found that financialization squeezed out the $\mathrm{R} \& \mathrm{D}$ and innovation of enterprises. In addition, the diversification theory also shows that there is potential risk in non-relevant diversification, and the existence of risk factors affects the exertion of synergy effects of diversification. Industrial-financial integration is the combination of industrial capital and financial capital. In essence, it is non-relevant diversification. The difference between the physical enterprise and the financial industry results in the combination of industrial-financial enterprises facing management risks brought by unrelated diversification, business risks, financial risks, and risks of core competitiveness decline, but also facing special risks brought by the financial industry. At this stage, although China's domestic integration of production and financing is common, there are actually a large number of ineffectiveness and negative effects. The main motivation of most listed companies is to pursue short-term integration. Profit, rather than from the perspective of strategic development, such 
a combination of industry and finance is difficult to exert diversified synergistic effects, but it is easy to increase risks and have a certain degree of negative impact on corporate innovation. Therefore, this article makes the following assumptions:

H1: The combination of industry and finance has a "crowding out" effect on corporate innovation

On the basis of demonstrating that the combination of industry and finance has a "basic effect" on corporate innovation, taking into account that different companies may face different internal environments, then further study the effect of industry and finance integration on corporate innovation from the perspective of corporate internal agency costs and corporate external financing constraints.

\subsection{Differential Analysis of the Impact of the Combination of Industry and Finance on Corporate Innovation under Different Agency Costs}

In corporate companies, the separation of ownership and management rights has created a problem of agency between management and shareholders. Under the agency problem, managers, as insiders of the company, have great discretion over the company's asset allocation decisions, and are motivated to use management rights for personal gain. The financial industry has higher profits than the industrial sector, and managers may enter the financial industry for speculative arbitrage for the purpose of obtaining short-term excess returns, thereby ignoring the long-term development of enterprises. At the same time, the characteristics of "heavy rewards and light penalties" for financial investment performance of enterprises have also encouraged the enthusiasm of managers to invest funds in the financial field. The higher the manager's income from financial investment, the higher his salary. However, if there is a loss in financial investment, the manager can blame these losses on external factors such as market risk, thereby reducing damage to his own interests. This has stimulated the financial investment behavior of managers to a certain extent. Ciamarra (2012) research found that in companies with serious agency problems, the increased control capacity brought by excessive industrial and financial financing makes it possible for managers to abuse credit funds and expand the size of enterprises through excessive investment to maximize their own benefits, which is not conducive Enterprise innovation. Therefore, the more serious the agency problem and the higher the agency cost, the more likely the industry-finance integration will deviate from the original intention of long-term strategic development and become a tool for short-term investment arbitrage. In this case, the squeeze-out effect of industry-finance integration on corporate innovation will be more significant. Therefore, this article proposes Hypothesis 2:

H2: Compared with companies with low agency costs, the "crowding out" effect of enterprise-finance integration on enterprise innovation is stronger in companies with high agency costs. 


\subsection{Differential Analysis of the Impact of Industry-Finance Integration on Enterprise Innovation under Different Financing Constraints}

Due to the existence of information asymmetry, the external financing cost of the company is higher than the internal financing cost. Because of the difficulty in accepting the high financing cost, the company has to abandon certain projects with a positive net present value. When a company faces higher external financing constraints, certain investment projects of the company will be forced to be interrupted due to lack of funds and unable to obtain funds from the outside, which will ultimately damage the overall interests of the company. An enterprise's innovation activity is a long-term investment activity. Compared with ordinary investment, the returns have greater uncertainty and higher risks. Moreover, for the purpose of protecting research and development, the information disclosure of innovation activities is also relatively less, and less transparent information, which further increases information asymmetry, and these characteristics of innovation activities that are different from general investment are more likely to lead to financing constraints. When companies face higher financing constraints, external financing becomes difficult, and at this time, their $\mathrm{R} \& \mathrm{D}$ and innovation activities will rely more on internal cash flow.

However, the overall resources available to enterprises are limited, and there is a mutual substitution relationship between financial investment and physical investment. If an enterprise chooses to enter the financial field at this time, it is necessary to decentralize some resources from the physical field to the financial field. This will reduce investment in corporate innovation activities. Therefore, this article proposes Hypothesis 3:

H3: Compared with companies with low financing constraints, the combination of industry and finance has a stronger "crowding out" effect on corporate innovation among companies with higher financing constraints.

\section{Research Design}

\subsection{Sample Selection and Data Source}

This article selects China A-share listed companies from 2008 to 2017 as the research sample, and performs sample screening according to the following steps: 1) Exclude listed companies in the financial industry and ST, PT listed companies; 2) Exclude listed companies that have not disclosed $R \& D$ investment data; 3) Exclude listed companies with missing key variable data. After screening through the above procedures, 14,837 sample observations were finally obtained. In the main regression, the explanatory variables used the data of the lagging period, so the sample observations that actually participated in the regression were 11920. In this article, the data of listed companies holding shares of non-listed financial institutions comes from Wind database, R \& D investment data comes from Guotai'an listed company's R \& D and innovation database (CSMAR), and other financial data comes from Guotai'an database (CSMAR). The leaks come from the annual report of listed companies published by Juchao Information 
Network. This article uses Excel 2010 for the basic processing of the data, Stata 11.0 for the operational analysis of the data. At the same time, in order to eliminate the influence of extreme values, this paper performs Winsorize processing on the $1 \%$ and $99 \%$ percentiles of all continuous variables. The following data analysis is based on the processed results.

\subsection{Variable Definition and Model Construction}

\subsubsection{Variable Definition}

1) Independent variable

Financing (Fin): With reference to the existing literature, this article selects the company's holding of non-listed financial institutions as the proxy variable for financing. Specifically, the company holds equity in banks, securities, funds, insurance, trusts, finance and futures companies. This article sets a dummy variable. If the company holds equity in an unlisted financial institution, it means that the company has combined industry and finance, with a value of 1 , and a value of 0 otherwise.

2) Dependent variable

$R$ \& D investment $(R \& D)$ : There are two main methods for measuring $R$ \& $D$ investment in academic circles, namely absolute indicators and relative indicators. Absolute indicators are measured using the natural logarithm of R \& D expenditure, and relative indicators are measured using the ratio of $\mathrm{R} \& \mathrm{D}$ income or the ratio of $\mathrm{R} \& \mathrm{D}$ assets. Considering that operating income is easily manipulated and unstable, this article uses the ratio of $R \& D$ assets, that is, $R \& D$ investment divided by total assets, as a measure of $\mathrm{R} \& \mathrm{D}$ investment.

3) Regulatory variables

Financing Constraint (KZ): The $\mathrm{KZ}$ indicator is calculated using the method of existing research. The larger the value, the higher the degree of financing constraints the company faces. The specific calculation method is as follows:

$$
\begin{aligned}
\mathrm{KZ}= & -1.001909 * \mathrm{OCF} / \text { Asset }+3.139193 * \text { Lev } \\
& -9.3678 * \text { Dividends/Asset } \\
& -1.314759 * \text { Cash } / \text { Asset }+0.226389 * \text { Tobin'Q }
\end{aligned}
$$$$
\text { Formula (1) }
$$

Among them, OCF, Dividends and Cash are operating net cash flow, cash dividends and cash holding levels, respectively, and are standardized using the beginning of the total assets. Lev and Tobin'Q represent corporate financial leverage and Tobin's $Q$ value respectively.

Agency cost (Agency_cost): This article draws on the practice of scholars such as Shouxi Li (2007) to adopt the management expense ratio, that is, the management expense divided by the operating income as a measure of the agency cost. The larger the indicator, the higher the agency cost of the enterprise.

4) Intermediate variables

Business Risk (Risk): This paper draws on the research of Zhai et al. (2014a) and adopts a 5-year rolling standard deviation of the annual average of individual stocks adjusted by the industry average to measure business risk [52]. The 
specific calculation method is as follows:

$$
\text { RiskT }_{i}=\sqrt{\frac{1}{N-1} \sum_{n=1}^{N}\left(\text { ADJ_return }_{\text {in }}-\frac{1}{N} \sum_{n=1}^{N} \text { ADJ_return }_{\text {in }}\right)^{2}} \mid N=5 \text { Formula (2) }
$$

5) Control variables

According to the existing research, this paper controls the enterprise size (Size), financial leverage (Lev), profitability (Roa), equity concentration (Share), operating cash flow (Cflow), company age (Age), annual control variables (Year), Industry control variable (Ind). The specific variable definitions are shown in Table 1.

\subsubsection{Model Construction}

1) Analysis of the impact of industry-finance integration on corporate innovation

Table 1. Definition of main variables.

\begin{tabular}{|c|c|c|c|}
\hline Variable type & Variable name & symbol & Variable definitions \\
\hline $\begin{array}{l}\text { Dependent } \\
\text { variable }\end{array}$ & $\mathrm{R} \& \mathrm{D}$ & $\mathrm{R} \& \mathrm{D}$ & $\mathrm{R} \& \mathrm{D}$ expenditure/total assets \\
\hline \multirow[t]{3}{*}{$\begin{array}{l}\text { Independent } \\
\text { variable }\end{array}$} & $\begin{array}{l}\text { Industry-Finance } \\
\text { Integration }\end{array}$ & Fin & $\begin{array}{l}\text { Dummy variable, if the company's } \\
\text { shareholding in an unlisted financial } \\
\text { institution is set to } 1 \text {, otherwise it is set to } 0\end{array}$ \\
\hline & Agency cost & Agency_cost & $\begin{array}{c}\text { Management expenses/operating } \\
\text { income, greater than the } \\
\text { median take } 1 \text {, otherwise } 0\end{array}$ \\
\hline & $\begin{array}{l}\text { Financing } \\
\text { constraints }\end{array}$ & $\mathrm{Kz} \_$index & $\begin{array}{l}\text { Dummy variable, if } \mathrm{KZ} \text { index is } \\
\text { greater than median, take } 1 \text {; } \\
\text { otherwise, take } 0 \text {. See Formula (1) }\end{array}$ \\
\hline \multirow[t]{5}{*}{$\begin{array}{l}\text { Mediation } \\
\text { variable }\end{array}$} & Operating risk & Risk & $\begin{array}{l}5 \text {-year rolling standard deviation } \\
\text { of annual stock returns adjusted by } \\
\text { industry average. See Formula (1) }\end{array}$ \\
\hline & Enterprise size & Size & Natural logarithm of total assets \\
\hline & Financial leverage & Lev & Total Liabilities/Total Assets \\
\hline & Profitability & Roa & Net profit/total assets \\
\hline & $\begin{array}{c}\text { Equity } \\
\text { concentration }\end{array}$ & Share & $\begin{array}{l}\text { The sum of the shareholdings } \\
\text { of the top five shareholders }\end{array}$ \\
\hline \multirow[t]{4}{*}{$\begin{array}{l}\text { Control } \\
\text { variable }\end{array}$} & $\begin{array}{l}\text { Operating } \\
\text { cash flow }\end{array}$ & Cflow & $\begin{array}{l}\text { Net cash flow from operating } \\
\text { activities/total assets }\end{array}$ \\
\hline & Company age & Age & $\begin{array}{l}\text { The current year minus the year of } \\
\text { establishment takes the natural logarithm }\end{array}$ \\
\hline & $\begin{array}{l}\text { Annual } \\
\text { control variable }\end{array}$ & Year & $\begin{array}{c}\text { The value of the year is } 1 \text {, } \\
\text { otherwise it is } 0\end{array}$ \\
\hline & $\begin{array}{c}\text { Industry } \\
\text { control variables }\end{array}$ & Ind & $\begin{array}{c}\text { The value of this industry is } 1 \text {, } \\
\text { otherwise it is } 0\end{array}$ \\
\hline
\end{tabular}


In order to test Hypothesis 1, this paper refers to the research of Tong Pan and Lu Zhengfei (2005) and combines the research purpose of this paper to build a model (1). In view of the company's $\mathrm{R} \& \mathrm{D}$ investment decision-making must be made prior to the implementation of the decision, and in order to avoid endogenous problems, this article lags all explanatory variables and control variables by one period.

$$
\mathrm{R} \& \mathrm{D}_{i, t}=\beta_{0}+\beta_{1} \text { Fin }_{i, t-1}+\beta_{2} \text { Control }_{i, t-1}+\sum \text { Year }+\sum \text { Ind }+\varepsilon \quad \text { Model (1) }
$$

Model (1) examines the impact of industry-finance integration on corporate innovation. Among them, $\mathrm{R} \& \mathrm{D}$ is the dependent variable, which represents the level of $\mathrm{R} \& \mathrm{D}$ investment of the company; Fin is the independent variable, which represents the company that combines industry and finance; Control is the relevant control variable; Year is the annual control variable, which controls the annual effect; Ind, the industry dummy variable, which controls the industry effect. According to the foregoing analysis, if hypothesis 1 holds, the coefficient of Fin in model (1) should be significantly negative.

2) Analysis of the impact of the combination of industry and finance on corporate innovation under different agency costs and financing constraints

In order to test Hypothesis 2 and Hypothesis 3, that is, to test whether the combination of industry and finance has a "crowding out" effect on corporate innovation under different financing constraints and different agency costs, this article refers to the existing research practices, according to the median of relevant variables The sample is divided into two sub-samples of high and low, and then a group test is performed according to model (1) to identify the difference in the "crowding out" effect of business-finance integration on corporate innovation under different financing constraints and different agency costs. According to the foregoing analysis, If Hypothesis 2 and Hypothesis 3 hold, then the Fin coefficient in the group (1) group test should be significantly negative in the group with high agency financing constraints and high agency costs.

\section{Analysis of Empirical Results}

\subsection{Descriptive Statistics}

Table 2 is the descriptive statistics of the main variables. As can be seen from Table 2, the average value of $\mathrm{R} \& \mathrm{D}$ is 0.0216 , the maximum value is 0.0979 , and the minimum value is 0.0001 . A large difference in extreme values indicates a large difference in $\mathrm{R} \& \mathrm{D}$ investment between listed companies in China, while a lower average value indicates a listed company in China. The overall level of $\mathrm{R} \&$ $\mathrm{D}$ investment is low. The mean value of Fin is 0.0940 , which indicates that some companies in China's listed companies have carried out industry-finance integration. In terms of control variables, the average value of Size is 21.8694, the maximum value is 25.7813 , and the minimum value is 19.7197 , indicating that the overall size of listed companies in China is not much different. The average value of Lev is 0.3850 , and the maximum value is 0.8585 , which indicates that debt financing is an important channel for Chinese listed companies to obtain 
funds, and the financial leverage ratio of some companies is too high, and there may be higher financial risks. The average value of Roa is 0.0527 , the maximum value is 0.2293 , and the minimum value is -0.1265 , which indicates that the overall gap in profitability of listed companies in China is large. The average value of Share is 0.5497 , which indicates that the concentration of equity in listed companies in China is relatively high. The average value of Cflow is 0.0438 , the maximum value is 0.2354 , and the minimum value is -0.1490 , which indicates that there is a large difference between the net cash flows of operating activities of listed companies in China. The average value of Age is 2.6135, the maximum value is 3.3673 , and the minimum value is 1.0986 , indicating that the overall age difference of listed companies in China is not large, and the life cycle stages are generally consistent.

\subsection{Correlation Coefficient Test}

Table 3 is the correlation coefficient table of the main variables. From the correlation coefficient table, it can be known that the correlation coefficient between industry-finance integration and R \& D investment is -0.111 , and it is significant at the level of $1 \%$. It is initially determined that the industry-finance integration has a certain crowding-out effect on the R \& D investment of listed companies in China. This fits the main hypothesis. From Table 3, except for individual

Table 2. Descriptive statistics of the main variables.

\begin{tabular}{ccccccc}
\hline variable & $\mathrm{N}$ & Mean & $\mathrm{Sd}$ & Min & Median & Max \\
\hline R \& D & 14,837 & 0.0216 & 0.0179 & 0.0001 & 0.0183 & 0.0979 \\
Fin & 14,837 & 0.0940 & 0.2919 & 0.0000 & 0.0000 & 1.0000 \\
Size & 14,837 & 21.8694 & 1.2415 & 19.7197 & 21.6882 & 25.7813 \\
Lev & 14,837 & 0.3850 & 0.2025 & 0.0431 & 0.3686 & 0.8585 \\
Roa & 14,837 & 0.0527 & 0.0558 & -0.1265 & 0.0472 & 0.2293 \\
Share & 14,837 & 0.5497 & 0.1491 & 0.2060 & 0.5545 & 0.8785 \\
Cflow & 14,837 & 0.0438 & 0.0678 & -0.1490 & 0.0419 & 0.2354 \\
Age & 14,837 & 2.6135 & 0.4441 & 1.0986 & 2.7081 & 3.3673 \\
\hline
\end{tabular}

Table 3. Correlation test of main variables.

\begin{tabular}{|c|c|c|c|c|c|c|c|c|}
\hline & $\mathrm{R} \& \mathrm{D}$ & Fin & Size & Lev & Roa & Share & Cflow & Age \\
\hline$R \& D$ & 1.000 & & & & & & & \\
\hline Fin & $-0.111^{\star * \star}$ & 1.000 & & & & & & \\
\hline Size & $-0.251^{\star * *}$ & $0.180^{\star * *}$ & 1.000 & & & & & \\
\hline Lev & $-0.222^{* * *}$ & $0.153^{\star * *}$ & $0.555^{\star * *}$ & 1.000 & & & & \\
\hline Roa & $0.235^{\star * *}$ & $-0.077^{\star * *}$ & $-0.152^{\star * *}$ & $-0.416^{\star * *}$ & 1.000 & & & \\
\hline Share & $-0.014^{*}$ & $-0.038^{\star \star \star *}$ & $0.030^{\star * *}$ & $-0.110^{\star * \star}$ & $0.239^{\star * *}$ & 1.000 & & \\
\hline Cflow & $0.100^{\star * *}$ & 0.008 & $0.031^{\star * *}$ & $-0.140^{\star * *}$ & $0.409^{\star * *}$ & $0.113^{\star * *}$ & 1.000 & \\
\hline Age & $-0.115^{\star * \star}$ & $0.029^{* * *}$ & $0.224^{\star * *}$ & $0.203^{\star * *}$ & $-0.150^{\star * \star}$ & $-0.229^{\star * *}$ & 0.013 & 1.000 \\
\hline
\end{tabular}

Note: The coefficients in the table are pears on correlation coefficients, where ${ }^{* *}$ means significant at the $1 \%$ level, ${ }^{* *}$ means significant at the $5 \%$ level, and ${ }^{*}$ means significant at the $10 \%$ level. 
variables, the correlation coefficients between the variables are all less than 0.5 . It can be considered that there is no serious collinearity problem between the variables. The preliminary determination of the data meets the prerequisites for performing multicollinear regression analysis.

\subsection{Multiple Regression Analysis}

\subsubsection{Analysis of the Regression Results of the Combination of Industry and Finance and Corporate Innovation}

Table 4 shows the regression results of the impact of industry-finance integration on corporate innovation. As can be seen from the table, with enterprise innovation as the independent variable and industry-finance integration as the dependent variable, after controlling the impact of other variables, the coefficient of industry-finance integration is significantly negative at the level of $1 \%$, indicating that the combination of industry-finance integration is an important factor for enterprise innovation. Has a significant "crowding out" effect, Hypothesis 1 is validated. This is mainly because the industry-financial integration

Table 4. Industry-finance integration and enterprise innovation.

\begin{tabular}{|c|c|}
\hline & $\mathrm{R} \& \mathrm{D}$ \\
\hline Variable name & (1) \\
\hline \multirow[t]{2}{*}{ Fin } & $-0.0017^{\star * *}$ \\
\hline & $(-4.0839)$ \\
\hline \multirow[t]{2}{*}{ Size } & $-0.0008^{* * *}$ \\
\hline & $(-5.1217)$ \\
\hline \multirow[t]{2}{*}{ Lev } & $-0.0023^{\star *}$ \\
\hline & $(-2.5043)$ \\
\hline \multirow[t]{2}{*}{ Roa } & $0.0414^{* * *}$ \\
\hline & (11.9978) \\
\hline \multirow[t]{2}{*}{ Share } & $-0.0034^{\star \star \star}$ \\
\hline & $(-3.6428)$ \\
\hline \multirow[t]{2}{*}{ Cflow } & $0.0186^{\star * *}$ \\
\hline & (7.5032) \\
\hline \multirow[t]{2}{*}{ Age } & $-0.0019^{\star * *}$ \\
\hline & $(-5.2413)$ \\
\hline \multirow[t]{2}{*}{ constant } & $0.0321^{\star * *}$ \\
\hline & $(8.5660)$ \\
\hline Industry & control \\
\hline Year & control \\
\hline $\mathrm{N}$ & 11920 \\
\hline adj. R-sq & 0.324 \\
\hline
\end{tabular}

Note: ${ }^{* *}$ means significant at the $1 \%$ level, ${ }^{* *}$ means significant at the $5 \%$ level, ${ }^{*}$ means significant at the $10 \%$ level. 
of Chinese enterprises are still in a period of obtaining short-term returns at this stage. This type of industry-financial integration under profit-seeking purposes tends to cause companies to deviate from long-term strategic objectives and cause industrial funds to idle in the financial system. The level of industrial investment is reduced, restricting R \& D and innovation of enterprises, and ultimately restricting the improvement of corporate competitiveness and long-term economic growth.

\subsubsection{Analysis of Regression Results of Agency Costs, Industry-Finance Integration and Enterprise Innovation}

Table 5 shows the regression results of the impact of the combination of production and finance on corporate innovation under different agency costs. Judging from the regression results, the coefficient of industry-finance integration

Table 5. Agency costs, industry-finance integration, and corporate innovation.

\begin{tabular}{|c|c|c|}
\hline & $\mathrm{R} \& \mathrm{D}$ & $\mathrm{R} \& \mathrm{D}$ \\
\hline Variable name & High agency costs (1) & Low agency costs (2) \\
\hline \multirow[t]{2}{*}{ Fin } & $-0.0031^{\star \star \star}$ & -0.0006 \\
\hline & $(-4.1083)$ & $(-1.3561)$ \\
\hline \multirow[t]{2}{*}{ Size } & 0.0000 & $-0.0010^{* * *}$ \\
\hline & $(0.1709)$ & $(-5.8032)$ \\
\hline \multirow[t]{2}{*}{ Lev } & 0.0007 & -0.0005 \\
\hline & $(0.4701)$ & $(-0.4350)$ \\
\hline \multirow[t]{2}{*}{ Roa } & $0.0522^{\star * *}$ & $0.0310^{* * *}$ \\
\hline & $(10.0360)$ & $(7.5813)$ \\
\hline \multirow[t]{2}{*}{ Share } & $-0.0044^{\star * *}$ & -0.0017 \\
\hline & $(-2.8721)$ & $(-1.5913)$ \\
\hline \multirow[t]{2}{*}{ Cflow } & $0.0236^{* * *}$ & $0.0133^{\star * *}$ \\
\hline & $(5.5632)$ & $(4.7094)$ \\
\hline \multirow[t]{2}{*}{ Age } & $-0.0028^{* * *}$ & $-0.0010^{* *}$ \\
\hline & $(-4.6492)$ & $(-2.5049)$ \\
\hline \multirow[t]{2}{*}{ constant } & $0.0151^{* *}$ & $0.0321^{* * *}$ \\
\hline & $(2.2220)$ & $(8.1624)$ \\
\hline Industry & control & control \\
\hline Year & control & control \\
\hline $\mathrm{N}$ & 6103 & 5817 \\
\hline adj. R-sq & 0.305 & 0.291 \\
\hline chi2 & & \\
\hline $\mathrm{p}$ & & \\
\hline
\end{tabular}

Note: ${ }^{* *}$ means significant at the $1 \%$ level, ${ }^{* *}$ means significant at the $5 \%$ level, ${ }^{*}$ means significant at the $10 \%$ level. 
is significantly negative at the level of $1 \%$ in enterprises with high agency costs; the coefficient of industry-finance integration is negative but not significant at enterprises with low agency costs. The results show that the higher the agency cost of a company is, the more "crowding out" effect of the industry-financial combination on the innovation of the company is. This is mainly because in companies with serious agency problems, it is easier to induce self-interest behavior of managers, and it is easier for managers to enter the financial field to obtain short-term excess returns, so that industry-finance integration becomes a tool for corporate speculation and arbitrage, ignoring the long-term enterprise development.

\subsubsection{Analysis of Regression Results of Financing Constraints,} Integration of Industry and Finance, and Enterprise Innovation

Table 6 shows the regression results of the impact of the combination of industry and finance on corporate innovation under different financing constraints. From the regression results, in the enterprises with high financing constraints,

Table 6. Financing constraints, industry-finance integration and corporate innovation.

\begin{tabular}{|c|c|c|}
\hline & $\mathrm{R} \& \mathrm{D}$ & $\mathrm{R} \& \mathrm{D}$ \\
\hline Variable name & High financing constraints (1) & Low financing constraints (2) \\
\hline \multirow[t]{2}{*}{ Fin } & $-0.0021^{\star * *}$ & -0.0011 \\
\hline & $(-4.1570)$ & $(-1.6074)$ \\
\hline \multirow[t]{2}{*}{ Size } & $-0.0006^{\star * \star}$ & $-0.0009^{* * *}$ \\
\hline & $(-2.9601)$ & $(-3.6567)$ \\
\hline \multirow[t]{2}{*}{ Lev } & $-0.0058^{* * *}$ & $0.0030^{*}$ \\
\hline & $(-4.2275)$ & $(1.6777)$ \\
\hline \multirow[t]{2}{*}{ Roa } & $0.0366^{\star * *}$ & $0.0467^{\star * *}$ \\
\hline & $(7.7507)$ & $(8.5177)$ \\
\hline \multirow[t]{2}{*}{ Share } & -0.0009 & $-0.0064^{\star * \star}$ \\
\hline & $(-0.6905)$ & $(-4.2448)$ \\
\hline \multirow[t]{2}{*}{ Cflow } & $0.0183^{* * *}$ & $0.0180^{* * *}$ \\
\hline & $(5.6739)$ & $(4.3395)$ \\
\hline \multirow[t]{2}{*}{ Age } & $-0.0021^{\star * *}$ & $-0.0017^{\star * \star}$ \\
\hline & $(-4.1589)$ & $(-3.1506)$ \\
\hline \multirow[t]{2}{*}{ constant } & $0.0280^{* * *}$ & $0.0401^{* * *}$ \\
\hline & $(6.1313)$ & $(6.3570)$ \\
\hline Industry & control & control \\
\hline Year & control & control \\
\hline $\mathrm{N}$ & 6528 & 5392 \\
\hline adj. R-sq & 0.331 & 0.312 \\
\hline
\end{tabular}

Note: ${ }^{* * *}$ means significant at the $1 \%$ level, ${ }^{* *}$ means significant at the $5 \%$ level, ${ }^{*}$ means significant at the $10 \%$ level. 
the coefficient of industry-finance integration is significantly negative at the level of $1 \%$; in the enterprises with low financing constraints, the coefficient of industry-finance integration is negative but not significant. The results show that compared with companies with low financing constraints, the higher the financing constraints faced by enterprises, the more significant the "crowding out" effect of industry-finance integration on corporate innovation. Hypothesis 3 is verified. This is mainly because the total amount of corporate resources is limited. The expansion of enterprises into the financial sector will certainly occupy resources for industrial investment and $\mathrm{R} \& \mathrm{D}$ innovation. This crowding out effect is among those with a high degree of financing constraints, limited own funds, and more dependent on external financing of companies are more significant. Enterprises with fewer financial restrictions are more likely to allocate resources between industry and financial investment, and the crowding out effect is relatively small.

\subsection{Robustness Test}

\subsubsection{Discussion on Endogenous Issues}

1) PSM tendency matching score

In order to avoid sample selection errors and endogenous problems, this paper uses the PSM propensity score ratio matching method for robustness testing. The specifics are as follows: This article selects the size of the company, financial leverage, profitability, equity concentration, operating cash flow, and corporate age as matching indicators, controls the year and industry, uses a radius of 0.001 to match, and obtains a matching sample. The previous method performs a regression test to control the effect of differences in the intrinsic characteristics of the company on the dependent variable.

Column (1) in Table 7 shows the regression results after matching the propensity scores. From the regression results of each column, the coefficient of industry-finance integration is still significantly negative at the level of $1 \%$, which is consistent with the previous results, indicating that the conclusion of this paper is robust.

2) Instrumental variable method

Enterprise innovation strategy itself may have an impact on the level of its financial asset allocation, thereby creating an endogenous problem of reverse causality. In order to control this endogenous problem as much as possible, this paper draws on the existing research practices and uses the average value of the number of non-listed financial institutions held by other companies in the same industry and the same year as the instrumental variable for the integration of industry and finance. Then re-estimated the original model. Theoretically speaking, companies in the same industry and the same year face similar external environments and industry characteristics, so there is a certain correlation between their financial integration and financial integration, but there is no evidence that other companies in the same industry and financial integration will Affects the company's innovation output, so this instrumental variable satisfies the requirements of relevance 
Table 7. Robustness tests on endogenous problems.

\begin{tabular}{|c|c|c|}
\hline & $\mathrm{R} \& \mathrm{D}$ & $\mathrm{R} \& \mathrm{D}$ \\
\hline Variable name & (1) & (2) \\
\hline \multirow[t]{2}{*}{ Fin } & $-0.0017^{\star \star *}$ & $-0.0173^{* * *}$ \\
\hline & $(-4.0857)$ & $(-9.6678)$ \\
\hline \multirow[t]{2}{*}{ Size } & $-0.0008^{\star * *}$ & $-0.0014^{\star * *}$ \\
\hline & $(-5.0915)$ & $(-8.3885)$ \\
\hline \multirow[t]{2}{*}{ Lev } & $-0.0023^{\star \star}$ & $0.0028^{* * *}$ \\
\hline & $(-2.5064)$ & $(3.0445)$ \\
\hline \multirow[t]{2}{*}{ Roa } & $0.0413^{* * *}$ & $0.0531^{\star \star \star}$ \\
\hline & $(11.9683)$ & $(15.1170)$ \\
\hline \multirow[t]{2}{*}{ Share } & $-0.0034^{\star * *}$ & $-0.0062^{\star * *}$ \\
\hline & $(-3.6419)$ & $(-6.4725)$ \\
\hline \multirow[t]{2}{*}{ Cflow } & $0.0186^{\star * *}$ & $0.0118^{* * *}$ \\
\hline & $(7.4802)$ & $(4.8651)$ \\
\hline \multirow[t]{2}{*}{ Age } & $-0.0019^{* * *}$ & $-0.0024^{* * *}$ \\
\hline & $(-5.2505)$ & $(-6.5295)$ \\
\hline \multirow[t]{2}{*}{ constant } & $0.0341^{* * *}$ & $0.0481^{\star * *}$ \\
\hline & $(8.9681)$ & (13.1019) \\
\hline Industry & control & control \\
\hline Year & control & control \\
\hline $\mathrm{N}$ & 11915 & 14837 \\
\hline adj. R-sq & 0.324 & 0.183 \\
\hline
\end{tabular}

Note: ${ }^{* *}$ means significant at the $1 \%$ level, ${ }^{* *}$ means significant at the $5 \%$ level, ${ }^{*}$ means significant at the $10 \%$ level.

and exogenousness.

Column (2) in Table 7 shows the regression results after using the instrumental variable method to deal with endogeneity. From the regression results in the table, the coefficient of industry-finance integration is still significantly negative at the level of $1 \%$. This conclusion shows that after controlling for endogeneity, the conclusion of this paper is still robust.

\subsubsection{Re-Measurement of Enterprise Innovation}

In order to avoid the errors caused by the measurement of the dependent variable, this article re-measures enterprise innovation with reference to existing research. First, according to the current practice, standardize the R \& D expenditure of the listed company with operating income for the year as a substitute for corporate innovation, and perform regression in accordance with the aforementioned method. Secondly, the previous sample observations of missing R \& D expenditure data are excluded. In order to avoid the problem of sample selection 
errors that may be caused by discarding missing values, this article records the sample observations of the year when $\mathrm{R} \& \mathrm{D}$ expenditure data is missing as 0 . This supplement was added to the original regression sample, and then regression was performed according to the aforementioned method. Finally, in order to further test the reliability of the results, this article uses the invention patent application status of the listed company as the explained variable to measure the output of the company's industry, finance, marriage, and post-innovation activities, and repeats the regression test above. The reason why the number of invention patent applications is adopted instead of the number of appearance patents and utility model patent applications is that the number of invention patent applications can better represent the substantial innovation of the enterprise.

Table 8 shows the remeasured regression results for the three dependent variables 1 ) is the regression result after $\mathrm{R} \& \mathrm{D}$ expenditure is standardized by operating income, 2) is the regression result after missing values for $\mathrm{R} \& \mathrm{D}$

Table 8. Robustness test of innovation indicators of replacement enterprises.

\begin{tabular}{|c|c|c|c|}
\hline & $\mathrm{R} \& \mathrm{D}$ & $\mathrm{R} \& \mathrm{D}$ & $\mathrm{R} \& \mathrm{D}$ \\
\hline Variable name & (1) & (2) & (3) \\
\hline \multirow[t]{2}{*}{ Fin } & $-0.0046^{* * *}$ & $-0.0009^{* * *}$ & $-0.1374^{* * *}$ \\
\hline & $(-4.2183)$ & $(-4.2860)$ & $(-3.0612)$ \\
\hline \multirow[t]{2}{*}{ Size } & -0.0004 & -0.0001 & $0.3606^{* * *}$ \\
\hline & $(-1.1830)$ & $(-0.6639)$ & $(24.4624)$ \\
\hline \multirow[t]{2}{*}{ Lev } & $-0.0511^{* * *}$ & $-0.0037^{\star * \star}$ & -0.0807 \\
\hline & $(-23.7639)$ & $(-7.2476)$ & $(-1.0182)$ \\
\hline \multirow[t]{2}{*}{ Roa } & 0.0022 & $0.0275^{\star * *}$ & $1.9564^{* * *}$ \\
\hline & $(0.3092)$ & (14.9994) & $(7.7855)$ \\
\hline \multirow[t]{2}{*}{ Share } & $-0.0126^{* * *}$ & $-0.0021^{\star * *}$ & $-0.1435^{*}$ \\
\hline & $(-5.3741)$ & $(-3.5646)$ & $(-1.6466)$ \\
\hline \multirow[t]{2}{*}{ Cflow } & -0.0015 & $0.0106^{* * *}$ & $0.5794^{\star * *}$ \\
\hline & $(-0.2796)$ & $(8.3570)$ & $(2.9452)$ \\
\hline \multirow[t]{2}{*}{ Age } & $-0.0059^{* * *}$ & $-0.0030^{\star * *}$ & $-0.0664^{\star *}$ \\
\hline & $(-7.0440)$ & $(-19.8168)$ & $(-2.0711)$ \\
\hline \multirow[t]{2}{*}{ constant } & $0.0778^{\star * *}$ & $0.0080^{\star * *}$ & $-7.5027^{\star * *}$ \\
\hline & $(8.9328)$ & $(4.4279)$ & $(-22.2043)$ \\
\hline Industry & control & control & control \\
\hline Year & control & control & control \\
\hline $\mathrm{N}$ & 11920 & 22144 & 8042 \\
\hline adj. R-sq & 0.384 & 0.463 & 0.272 \\
\hline
\end{tabular}

Note: ${ }^{* * *}$ means significant at the $1 \%$ level, ${ }^{* *}$ means significant at the $5 \%$ level, ${ }^{*}$ means significant at the $10 \%$ level. 
expenditure, and 3) is the regression result after applying invention patent application data. As can be seen from the table, after re-measurement of enterprise innovation, the coefficient of the combination of production and finance is still significantly negative at the level of $1 \%$, and the results obtained are consistent with the above, indicating that the conclusion of this article is robust.

\subsection{Further Research: Analysis of the Mechanism of the Combination of Industry and Finance Affecting Corporate Innovation}

Many studies have pointed out that the combination of industry and finance is not $100 \%$ benefit and harmless, and may contain huge operating risks. Moreover, the risks of industry-finance integration are more hidden, systematic, and destructive than those of general organizational models (Hu \& Li, 2016). Under incomplete capital market conditions, company-specific risks are significantly negatively related to corporate investment behavior. Therefore, under the conditions of risk tolerance, when financial asset allocation brings higher corporate risks, risk-averse management decisions are more cautious, which will inhibit corporate investment behavior. In order to avoid the risk of corporate investment in innovation, management will tend to delay or terminate innovation investment to reduce future risks of the enterprise, thereby crowding out innovation investment. In view of this, this article further explores the role of the combination of industry and finance to "squeeze out" the innovation path of the enterprise from the perspective of operational risk. Zhai et al. (2014b)'s methods for measuring business operating risks, the industry average adjusted annual stock returns are used to measure the business risk using a 5-year rolling standard deviation.

Based on the foregoing research, we have verified the "crowding out" effect of industry-finance integration on corporate innovation. In order to further explore the mechanism of the integration of industry and finance to squeeze out the innovation of enterprises, this article follows the action path of "the combination of industry and finance, business risk, and enterprise innovation" and refers to the test of the mediation effect of Zhonglin Wen et al. (2004). On top, build model (2) and model (3) as follows:

$$
\begin{aligned}
& \text { Risk }_{i, t}=\alpha_{0}+\alpha_{1} \text { Fin }_{i, t-1}+\alpha_{2} \text { Control }_{i, t-1}+\sum \text { Year }+\sum \text { Ind }+\varepsilon \quad \text { Model (2) } \\
& \mathrm{R} \& \mathrm{D}_{i, t}=\varphi_{0}+\varphi_{1} \operatorname{Fin}_{i, t-1}+\varphi_{2} \operatorname{Risk}_{i, t-1}+\varphi_{3} \operatorname{Control}_{i, t-1} \\
& +\sum \text { Year }+\sum \text { Ind }+\varepsilon
\end{aligned}
$$

Table 9 shows the regression results of the mechanism by which industry-finance integration affects corporate innovation. From the regression results, the coefficient of the combination of production and finance in column: 1) is significantly negative at the level of $1 \%$, indicating that the combination of production and finance has "squeezed out" enterprise innovation. 2) The coefficient of the combination of industry and finance is significantly positive at the level of $5 \%$, which indicates that the combination of industry and finance has increased 
Table 9. Mechanisms of industry-finance integration affecting enterprise innovation.

\begin{tabular}{|c|c|c|c|}
\hline & $\mathrm{R} \& \mathrm{D}$ & Risk & $\mathrm{R} \& \mathrm{D}$ \\
\hline Variable name & (1) & $(2)$ & (3) \\
\hline \multirow[t]{2}{*}{ Fin } & $-0.0018^{* * *}$ & $0.0215^{* *}$ & $-0.0018^{* * *}$ \\
\hline & $(-4.4011)$ & $(2.1853)$ & $(-4.3211)$ \\
\hline \multirow[t]{2}{*}{ Risk } & & & $-0.0014^{\star * *}$ \\
\hline & & & $(-3.5585)$ \\
\hline \multirow[t]{2}{*}{ Size } & $-0.0008^{* * *}$ & $-0.0721^{\star * *}$ & $-0.0009^{* * *}$ \\
\hline & $(-5.0012)$ & $(-14.9444)$ & $(-5.5003)$ \\
\hline \multirow[t]{2}{*}{ Lev } & $-0.0018^{\star}$ & $0.1365^{* * *}$ & $-0.0017^{\star}$ \\
\hline & $(-1.8320)$ & $(3.8645)$ & $(-1.7104)$ \\
\hline \multirow[t]{2}{*}{ Roa } & $0.0396^{* * *}$ & $-0.3294^{* * *}$ & $0.0392^{\star * *}$ \\
\hline & $(9.8512)$ & $(-2.6956)$ & $(9.7346)$ \\
\hline \multirow[t]{2}{*}{ Share } & $-0.0034^{* * *}$ & $0.1146^{* * *}$ & $-0.0033^{\star * \star}$ \\
\hline & $(-3.4958)$ & $(4.0549)$ & $(-3.3455)$ \\
\hline \multirow[t]{2}{*}{ Cflow } & $0.0232^{\star * *}$ & -0.0248 & $0.0230^{* * *}$ \\
\hline & $(8.4829)$ & $(-0.2627)$ & $(8.4424)$ \\
\hline \multirow[t]{2}{*}{ Age } & $-0.0021^{* * *}$ & $-0.0377^{\star * *}$ & $-0.0021^{\star * *}$ \\
\hline & $(-5.3302)$ & $(-3.9978)$ & $(-5.4294)$ \\
\hline \multirow[t]{2}{*}{ Growth } & -0.0006 & $0.1172^{* * *}$ & -0.0005 \\
\hline & $(-1.6342)$ & $(8.4096)$ & $(-1.2167)$ \\
\hline \multirow[t]{2}{*}{ Captial } & $-0.0066^{* * *}$ & $-0.1975^{\star * *}$ & $-0.0069^{* * *}$ \\
\hline & $(-5.5821)$ & $(-6.2058)$ & $(-5.8209)$ \\
\hline \multirow[t]{2}{*}{ Constant } & $0.0370^{* * *}$ & $2.2726^{\star * *}$ & $0.0393^{* * *}$ \\
\hline & $(9.3168)$ & $(23.3085)$ & $(9.6417)$ \\
\hline Industry & control & control & control \\
\hline Year & control & control & control \\
\hline $\mathrm{N}$ & 10673 & 10656 & 10656 \\
\hline adj. R-sq & 0.332 & 0.162 & 0.333 \\
\hline
\end{tabular}

Note: ${ }^{* * *}$ means significant at the $1 \%$ level, ${ }^{* *}$ means significant at the $5 \%$ level, ${ }^{*}$ means significant at the $10 \%$ level.

the business risk of the enterprise. 3) The coefficient of industry-finance integration is significantly negative at the level of $1 \%$, and the operating risk coefficient is significantly negative at the level of $10 \%$, indicating that after the industry-finance integration of the enterprise, the business risk assumed is greater, while the business risk The rise eventually "crowded out" innovation investment. Therefore, operating risk is an intermediary factor that affects the combination of industry and finance and corporate innovation, and plays a part of the intermediary effect to the extent of the impact. 


\section{Conclusion and Outlook}

\subsection{Research Conclusions}

This article focuses on the impact of industrial-financial integration on corporate innovation in the context of China's economic transformation. An empirical test was performed based on the data of non-listed financial institutions held by A-share listed companies. The empirical test results show that the combination of industry and finance has a significant "crowding out" effect on the corporate innovation of China's listed companies. Further group tests show that, compared with companies with low agency costs and low financing constraints, the "crowding out" effect of industry-finance integration on corporate innovation is more pronounced in enterprises with high agency costs and high financing constraints. In addition, this article further explores the mechanism of the combination of industry and finance to "squeeze out" the innovation of enterprises, and finds that the combination of industry and finance increases the business risk of the enterprise, which in turn squeezes out innovation. The above research results fully show that China's domestic financial integration is still at a low level of pursuing short-term benefits at this stage. Enterprises enter the financial field not for long-term strategic purposes, but for the impulse of capital for profit. The financial integration has not effectively exerted the integration effect of industrial capital and financial capital, but has further increased the business risks of enterprises and suppressed the innovation investment of enterprises. This type of industrial-financial integration is not only detrimental to the long-term development of the enterprise, but has also harmed the value of the enterprise. And in the long run, the real economy may also be threatened by "destabilization". Therefore, at this stage, enterprises must change the concept of combining production and finance, and based on the long-term development of the enterprise, only in this way can really realize the purpose of "promoting production through finance". The research conclusions of this paper further enrich the literature on the economic consequences of the integration of industry and finance, and also provide empirical support for the theoretical practice of the combination of industry and finance.

This article conducts an empirical test on the relationship between the integration of industry and finance of listed companies and corporate innovation. Although some results have been achieved, due to the existence of some subjective and objective factors, the following problems still need to be improved:

1) This article does not distinguish between different shareholding ratios and the differentiating effects of shareholding types. Future research can further study the differential impact of the combination of industry and finance on corporate innovation in terms of the proportion of shares and types of shares in the combination of industry and finance.

2) This article only sets the dummy variable of whether to hold a financial institution as a substitute variable for the combination of industry and finance. There may be deviations in the measurement of the combination of industry and 
finance. If future research can find a more accurate quantitative way to measure the degree of interaction between industry and finance, it will make the research results more accurate and more practical.

\subsection{Suggestions}

1) Improve relevant laws and regulations and rectify chaos

With the increasing downward pressure on the economy and the chaos of industrial-financial integration, many companies have deviated from their main businesses and flooded into the financial industry to carry out speculative arbitrage. It has become a reality that the threat of "depreciation to reality" has further increased. In order to give full play to the effectiveness of financial service entities and achieve true "promote production through financing", the government must accelerate the improvement of laws and regulations related to the integration of industry and finance. Supervisory agencies such as the SASAC should also strengthen the incentives for enterprises to combine industry and finance. Review and evaluate the performance of the company's main business after the combination of industry and finance, severely crack down on short-term speculation based on speculative arbitrage motives, actively guide physical enterprises to adhere to industry-led, implement the goal of "financial services to the real economy", and promote the Sustainable development.

2) Strengthening the supervision of industry-finance integration access to prevent and control the risks of industry-finance integration

Although the integration of industry and finance has developed rapidly in China, its effectiveness is not high. Most enterprises still stay in the primary stage of industry and finance integration. A company often holds shares in multiple financial institutions. The blind expansion of industry-finance integration has caused chaos in its internal equity structure and corporate governance structure, increasing the risk of industry-finance integration and the possibility of speculative arbitrage. To this end, the supervisory authority must strengthen access management, strictly enforce access standards, strengthen qualification approval, and prevent rushing and blind comparisons. In addition, in order to prevent and control the risks associated with the combination of industry and finance, the supervisory department should explore the establishment of an indicator system for the combination of industry and finance, effectively establish a "firewall", and keep the bottom line of not having systemic financial risks. Regulatory indicators need to cover key financial indicators such as capital adequacy ratios and liquidity, as well as indicators involving large internal transactions and connected transactions between the physical and financial sectors.

3) Based on the development of the main business and give play to the synergistic effect of industry and finance

The ultimate goal of the integration of industry and finance is to realize the promotion of production through finance. Enterprises must not only confine themselves to the pursuit of high profits in the financial industry, but ignore the long-term development of their main businesses. Although financial capital can 
bring high short-term benefits to enterprises, such excess returns will fluctuate sharply with changes in macroeconomics, and have greater uncertainty. The main business is the foundation for the survival and development of an enterprise, and it is the key to preventing and controlling risks. If you blindly chase the excess income of the financial industry and ignore the development of the main business, it will increase the overall business risk of the enterprise. When the macroeconomic environment changes and the capital market is bearish, excessive investment in resources in the financial industry will have a strong impact on corporate development. Therefore, the industry-financial integration enterprise should take the company's main business as the core, establish a long-term development concept, give full play to the integration effect of industrial capital and financial capital, and use the power of financial capital to promote corporate strategic transformation and innovation and upgrade, and fully realize industrial capital. With the cyclic transformation of financial capital, give full play to the synergistic effect of "financing production with finance and promoting production with finance".

\section{Conflicts of Interest}

The author declares no conflicts of interest regarding the publication of this paper.

\section{References}

Alexander, G. (1962). Economic Backwardness in Historical Perspective: A Book of Essay. Cambridge, MA: Harvard University Press.

Arrow, K. J. (1962). Economic Welfare and the Allocation of Resources for Invention. In The Rate and Direction of Inventive Activity: Economic and Social Factors (pp. 609-626). Princeton, NJ: Princeton University Press. https://doi.org/10.1515/9781400879762-024

Chang, S.-C., \& Wu, H.-M. (2006). Production Experiences and Market Structure in R \& D Competition. Journal of Economic Dynamics \& Control, 30, 163-183. https://doi.org/10.1016/j.jedc.2004.12.001

Chen, Y. (2006). Evolution of Financial Risk Management: Motivation, Impact and Enlightenment. Journal of Central University of Finance and Economics, No. 7, 32-36.

Ciamarra, E. S. (2012). Monitoring by Affiliated Bankers on Board of Directors: Evidence from Corporate Financing Outcomes. Financial Management, 41, 665-702. https://doi.org/10.1111/j.1755-053X.2012.01191.x

Du, C. Z., Wang, F., \& Jiang, Y. F. (2014). Analysis of the Motives and Efficiency of the Industrial-Financial Integration of China's Industrial Listed Companies-Based on the Perspective of Equity-Listed Financial Institutions. Economic and Management Research, No. 4, 84-90.

Du, Y., Xie, J., \& Chen, J. Y. (2019). CEO Financial Background and Financialization of Real Enterprises. China Industrial Economy, No. 5, 136-154.

Guo, M. X., \& Liao, H. (2013). Research on the Motives and Effects of Private Enterprises' Participation in Banks-The Above Private Enterprises as an Example. Economic Review, No. 2, 85-92 
Hall, B. H., \& Lerner, J. (2010). The Financing of $R$ \& $D$ and Innovation. NBER Working Paper No. 15325. https://doi.org/10.3386/w15325

Hu, H., \& Li, J. (2016). On the Definition of the Combination of Industry and Finance from the Perspective of Subject. Beijing Financial Review, No. 3, 27-33.

Jiang, F. X., Wang, Z. J., \& Bai, J. H. (2013). The Dual Effects of Environmental Regulation on Technological Innovation: An Empirical Study Based on the Dynamic Panel Data of Jiangsu Manufacturing Industry. China Industrial Economy, No. 7, 44-55.

La Porta, R. et al. (2003). Relate Lending. The Quarterly Journal of Economics, 118, 231-268.

Laeven, L. (2003). Does Financial Liberalization Reduce Financing Constraints? Financial Management, 32, 5-34. https://doi.org/10.2307/3666202

Li, S. X. (2007). Property Right, Agency Cost and Agency Efficiency. Economic Research, No. 1, 102-113.

Li, S. X., \& Greenwood, R. (2004). The Effect of Within-Industry Diversification on Firm Performance: Synergy Creation, Multimarket Contact and Market Structuration. Strategic Management Journal, 25, 1131-1153. https://doi.org/10.1002/smj.418

Li, W., \& Cai, Y. (2019). Combination of Industry and Finance: "Boost the Main Business" or "Drop from Reality to Falsehood"?-A Study Based on Financial Institutions of Listed Companies Holding Shares. Friends of Accounting, No. 3, 63-67.

Li, W., \& Ma, C. (2014). "Industry + Finance" Industry-Finance Combination Model and Enterprise Investment Efficiency: Based on the Research of Chinese Listed Companies Holding Financial Institutions. Financial Research, No. 11, 109-126.

Li, X. C. (2011). Capital Market and the Growth of Chinese Entrepreneurs: Status Quo and Future, Problems and Suggestions-2011. Thematic Investigation Report on the Growth and Development of Chinese Enterprise Operators. Management World, No. 6, 76-90.

Lin, Y. (2010). Analysis of the Effect of the Combination of Industry and Finance of Listed Companies in China-An Empirical Study Based on the Perspective of Participating in Non-listed Financial Institutions. Nankai Management Review, 13, 153-160.

Lin, Z. Y., Lin, H. C., \& Deng, X. H. (2013). Income Tax Reform and Technological Innovation of Chinese Enterprises. China Industrial Economy, No. 3, 111-123.

Lu, R. (2014). Enterprise Innovation Investment and the Sensitivity of Executive Pay Performance. Accounting Research, No. 10,36-42+96.

Lu, T., \& Dang, Y. (2014). Corporate Governance and Technological Innovation: Comparison by Industry. Economic Research, 49, 115-128.

Orhangazi, O. (2008). Financialisation and Capital Accumulation in the Nonfinancial Corporate Sector: A Theoretical and Empirical Investigation on the U.S. Economy: 1973-2003. Cambridge Journal of Economics, 32, 863-886. https://doi.org/10.1093/cje/ben009

Pan, M., \& Yuan, G. Z. (2019). The Impact of Financial Intermediate Innovation on Enterprise Technology Innovation. China Industrial Economy, No. 6, 117-135.

Porter, M. E. (1992). Capital Disadvantage: America's Failing Capital Investment System. Harvard Business Review, 70, 65-82.

Qi, L., \& Wang, Y. B. (2013). Analysis on the Impact of State-Owned Bank Monopoly-Based on the Perspective of Industrial Technology Innovation. China Industrial Economy, No. 7, 69-80.

Romer, P. M. (1990). Endogenous Technological Change. The Journal of Political Economy, 98, S71-S102. https://doi.org/10.3386/w3210 
Schumpeter, J. (1942). Capitalism, Socialism and Democracy. New York: Harper.

Solow, R. M. (1957). Technical Change and the Aggregate Production Function. The Review of Economics Statistics, 39, 312-320. https://doi.org/10.2307/1926047

Tadesse, S. (2002). Financial Architecture and Economic Performance: International Evidence. Journal of Financial Intermediation, 11, 429-454. https://doi.org/10.1006/jfin.2002.0352

Tang, Y. J., \& Zuo, J. (2014). Nature of Ownership, Governance of Major Shareholders and Corporate Innovation. Financial Research, No. 6, 177-192.

Tong, P., \& Lu, Z. (2005). Liability Financing, Liability Sources and Corporate Investment Behavior-Empirical Evidence from Chinese Listed Companies. Economic Research, No. 5, 75-84 + 126 .

Wan, L. Y., Liao, M. Q., \& Hu, Y. (2015). Combination of Industry and Finance and Corporate Financing Constraints: An Empirical Study Based on Listed Companies' Participating Banks. Nankai Management Review, 18, 64-72 + 91.

Wang, C. H. (2004). Analysis of the Economic Effects of China's Domestic Integration. Financial Theory and Practice, No. 8, 6-8.

Wang, C., Zhang, R., \& Xie, L. (2016). Industry-Financial Integration, Financial Development and Corporate Innovation: Empirical Evidence from Financial Institutions Held by Listed Companies in Manufacturing Industries. Research and Development Management, 28, 71-81

Wang, H. J., Cao, Y. Q., Yang, Q., \& Yang, Z. (2017). The Financialization of Real Enterprises Promotes or Inhibits Corporate Innovation-Based on the Empirical Research of Listed Companies in Chinese Manufacturing Industry. Nankai Management Review, 20, 155-166.

Wang, H., Li, M., \& Tang, T. (2016). Driving Factors of Cross-Industry Arbitrage of Real Enterprises and Their Impact on Innovation. China Industrial Economy, No. 11, 73-89.

Wang, J. Z. (2018). Research on the Impact of the Intergenerational Age Gap between Chairman and CEO on Enterprise R \& D Investment. Financial Review, 10, 68-86 + 125.

Wang, Y. J., \& Feng, X. (2018). Reform of Administrative Approval System and Enterprise Innovation. China Industrial Economy, No. 2, 24-42.

Wen, Z., Zhang, L., Hou, J., \& Liu, H. (2004). Procedure and Application of Intermediate Effect Test. Chinese Journal of Psychology, No. 5, 614-620.

$\mathrm{Wu}, \mathrm{Y}$. B. (2012). Which Type of Ownership Enterprise in China Is the Most Innovative? World Economics, 35, 3-25 + 28-29 + 26-27.

Xie, J., Wang, W., \& Jiang, Y. (2014). Financialization of Manufacturing Industry, Government Control and Technological Innovation. Economic Developments, No. 11, 78-88.

Xie, W. M., \& Fang, H. X. (2011). Financial Development, Financing Constraints and Enterprise R \& D Investment. Financial Research, No. 5, 171-183.

Yang, Z., Li, M., \& Liu, F. (2019). Combination of Industry and Finance and Technical Innovation of Real Enterprises: Promoting or Restraining-An Empirical Study Based on Financial Institutions Holding Real Enterprises. Macroeconomic Research, No. 10, 62-77.

Yao, D. Q., Wang, S., Luo, C. Q., \& Huang, X. J. (2011). An Empirical Study on the Evaluation of the Operational Efficiency of Industry-Finance Combined Listed Companies. China Soft Science, No. 3, 140-148.

Yu, Y. H., Zhao, Q. F., \& Ju, X. S. (2018). Inventor Executives and Corporate Innovation. 
China Industrial Economy, No. 3, 136-154.

Zhai, S., Zhang, S., Xie, L., \& Zheng, J. (2014a). Bank Connectivity and Enterprise Risk-Based on the Empirical Evidence of Listed Companies in China. Management World, No. 4, 53-59.

Zhai, S., Zhang, S., Xie, L., \& Zheng, J. (2014b). Bank Affiliation and Corporate Risk: Empirical Evidence Based on Internal Listed Companies. Management World, No. 4, 53-59.

Zhang, L. T. (2017). Research on Institutional Environment, Industry-Finance Integration and Enterprise Operational Risk. Beijing: University of International Business and Economics.

Zhang, Q. L., \& Sun, J. T. (2007). Enterprise Performance Analysis of the Effectiveness of China's Domestic Integration and Integration. China Industrial Economy, No. 7, 96-102.

Zhi, Y., \& Wu, H. B. (2011). Motivation of Industry-Finance Integration in a Dynamic Competitive Environment-Based on the Endogenous Perspective of Competitive Advantage. Accounting Research, No. 11, 72-77 + 93 .

Zhong, T., \& Wang, C. Y. (2017). Financial Development and Enterprise Innovation Output-Based on the Comparative Perspective of Different Financing Models. Financial Research, No. 12, 127-142.

Zhou, H., \& Tan, Y. (2018). Industrial Policy, Integration of Industry and Finance and Corporate Financing Constraints. East China Economic Management, 32, 83-89.

Zhu, D. S., \& Zhou, X. P. (2016). Equity Checks and Balances, Executive Shareholding and Enterprise Innovation Efficiency. Nankai Management Review, 19, 136-144. 